\title{
Prophetic Communication: Transcendental Dimension In Islamic Philanthropy Messages
}

\author{
Yuliana Rakhmawati \\ Universitas Trunojoyo Madura \\ yuliana.r@trunojoyo.ac.id
}

\begin{abstract}
Indonesia Islamic philanthropy had been growing tremendously. Trends in institutions platforms in managing Islamic philanthropy brought the divergence of channel message distribution. Those institutions made convergence interdisciplinary innovation. Islamic philanthropy institutions obligate to distribute the message in an ethical manner. They employed prophetic communication values in engaging the public sphere with persuasive communication commonly. Prophetic communication design is a custom to promote transcendental dimension of contemporary communication praxis. The prophetic term uses the cognition proximity design refers to Prophet Muhammad as a role model. This research was conducted to get an overview of the prophetic communication representation in the Islamic philanthropic messages distribution. Analytical techniques use qualitative document analysis. The subject in this research is the display of text on the site of Islamic philanthropic foundations official website Rumah Zakat, Yayasan Dana Al-Falah, and Lembaga Manajemen Infaq. The theme categories enrich found with selective coding. The results of the analysis are discussed using the concepts of prophetic communication, message production theory, goal-planaction theory, action-making theory, and cognitive dissonance theory. For further research could obtain from the communication management of more specific philanthropic objects.
\end{abstract}


[Filantropi Islam di Indonesia mengalami perkembangan yang sangat pesat. Pengarusutamaan pengelolaan filantropi oleh lembaga membawa kanal dalam distribusi pesan filantropi semakin beragam. Inovasi dilakukan oleh penyelenggara filantropi Islam secara interdisipliner secara konvergen. Obligasi dalam distribusi pesan lembaga filantropi Islam dilakukan dengan menggunakan perspektif komunikasi profetik. Desain komunikasi profetik merupakan bentuk kontemporer dalam kajian komunikasi dengan mengedepankan dimensi transedental dan persuasif dalam praktis komunikasi. Terminologi profetik mendekati pesan dengan pola desain kognisi yang merujuk pada komunikasi nabi Muhammad. Kajian ini bermaksud untuk mengungkap representasi komunikasi profetik dalam pesan lembaga filantropi Islam yang tercermin dalam narasi teks. Teknik Analisis menggunakan metode analisis isi dokumen kualitatif, untuk kemudian dilakukan kategorisasi tematik atas temuan. Subjek dalam riset ini adalah teks dalam situs lembaga filantropi Islam. Media online dengan skema situs resmi dari tiga lembaga filantropi Islam di Indonesia yaitu: Rumah Zakat, yayasan Dana Al Falah, dan Lembaga Manajenen Infaq.Temuan yang didapatkan dari riset ini bahwa nilai komunikasi profetik telah digunakan oleh lembaga-lembaga filantropi Islam. Hasil analisis dibahas dengan menggunakan kaidah komuniksi profetik, teori produksi pesan, teori tujuan-rencana-aksi, teori penyusunan aksi, dan teori disonansi kognitif. Untuk riset selanjutnya dapat menggunakan objek filantropi yang lebih khusus seperti dalam manajemen komunikasi lembaga filantropi.]

Keywords: channel; message; Islamic philanthropy; persuasive; prophetic communication

\section{Introduction}

As one of the ten largest countries with Muslim populations in the world, Indonesia has the potential of human resources, the natural advantages, and historical benefits. ${ }^{1}$ The contribution of Muslims in

\footnotetext{
${ }^{1}$ Pew Research Center's Forum on Religion and Public Life, "The Future of the Global Muslim Population," Pew Research Center, 2011, http://www.pewforum.org/2011/01/27/the-future-of-the-global-muslim-population/. (accessed October 22, 2016).
} 
Indonesia in a variety of social and state disciplines, especially in the empowerment of the people is enormous. Human nature tends to do positive and noble things such as in philanthropy. People's generosity is one of the potentials that can be mobilized and optimized. In generosity context, charity place as a potential Islamic social capital investment. The concern in emerging the potential of the $u m m a h^{2}$ generosity is the key to Islamic philanthropy succeeds. This rule requires a standardized and professional managerial concept of deliberating Islamic philanthropy tasks.

Diverse philosophical perspectives embed with the exploration of potential generosity values. Golden rules doctrine works closely relate with generosity as a religious point of view; it puts the desire and priority of others beyond ours. Islam teaches philanthropy in several forms such as zakat, infaq, and sadaqah. The Islamic perspective views that humans are equipped with the natural desire to donate prosperity, energy, thought, time, and comfort for others. Islam also teaches philanthropy in obligation (mandatory) and voluntary (sunnah) form. Obligation refers to zakat (almsgiving) ${ }^{3}$ and sadaqah (voluntary giving).

"They were only commanded to worship God, devoting their faith to Him alone, and to practice regular prayer, and to give the purifying charity - that is the upright religion" (Al-Quran Al-Bayyinah: 5).

\footnotetext{
${ }^{2}$ Ummah refers to individual/s or groups of individuals who have faith in Islam as a religious affiliation. Ismā'‘̂ll Rājī al Fārūqī, "THE PRINCIPLE OF THE UMMAH," in Al Tawhid, 2019, 103-28, doi:10.2307/j.ctvk8w28n.12.

3 Monzer Kahf (2003) mention in his paper about the another form of Islamic almsgiving called waqf. He did found that real innovations in the idea of Waqf came in the early Islamic Period in Madinah. It started with the Prophet Muhammad when he asked for some one to buy the well of Bayruha' and designate it as free public utility for drinking water. This brought about a wide range of A wqaf that serve the welfare of the society in all and their different aspects. Also see Ahmad Bello Dogarawa Dogarawa, "Poverty Alleviaton through Zakah and Waqf Institutions: A Case for the Muslim Ummah in Ghana," SSRN Electronic Journal, 2012, doi:10.2139/ssrn.1622122.
} 
"Successful are the believers, Those who are humble in their prayers, Those who avoid nonsense, Those who work for charity" (Al-Quran Al-Mukminun: 1-4)

The above verse is one form of command in religious life in Islam. It states that in every fortune that Muslims get there is a right portion from others. In the Islamic concept of property is ownership that must be "cleansed". The mechanism for cleansing assets is done by issuing zakat or giving alms. Prompts to issue alms for wealth obtained by Muslims are also conveyed in paragraph:

"And give them of God's wealth, which he has given you" (An Nur: 33).

The lessons of distributing some of these Muslim assets when learned have various benefits such as in economic and social dimensions. The potential of zakat and alms of Indonesian Muslims can be explored and used for the empowerment of the people, which in turn will create the independence of the people. The willingness and awareness of Muslims to deliver zakat (as an obligation) and donate alms (as a form of Sunnah appeal) combined with maximum management and distribution management and good governance can give birth to a professional empowerment system.

In the social science perspective charity or altruism activities as practiced by Muslims are called philanthropy. Generosity carried out in philanthropic schemes is not just a form of charity (fundraising and distribution), but also requires sustainability. Philanthropic punctuated activities began with raising, managing, distributing, evaluating programs, and sustainability. The concept of philanthropy relates to the understanding of altruism, which understands that the self will give priority to others. Rakhmawati ${ }^{4}$ writes that philanthropy is an activity

${ }^{4}$ Yuliana Rakhmawati, "MADURA :," in MADURA: Masyarakat, Budaya, Media, Dan Politik, ed. Surokim (Bangkalan: Elmatera Publishing, 2015), 117-34. 
that invites individuals to share with others with various forms of giving. Philanthropy is generally carried out from the modest dimension by involving individuals; remain from the domestic domain to involving structured institutions and applying the principles of good corporate governance.

The principle of caring and sharing in Islam is a moral manifestation in religious philanthropy. Historically, in the traditional custom culture, Islam as a religion has also conveyed the principle of generosity. More specifically, the charity patterns in Islam determine in the form of standard manuals procedure not only in fundraising but also in distribution. Islamic philanthropy has been known and practiced since prophetic epoch and developed stretches the social dynamics of society.

The potential of Indonesian Muslims in the economic, social and human resources sectors plays as constructive contributor to Indonesia's development. In economic perspectives, Indonesian muslim contributes significantly to economic empowerment. Indonesia becomes the fifth greatest country with Muslim population and it is still growing. The empowerment of undertaken pattern requires a mechanism and particular approach. Those plentiful Muslim potential plays as catalyst for optimizing people potential development to the maximum limitation. It is encouraging that in the midst of skeptical news about Islam, remain with the growth and development of generosity values of Islamic entities.

In the Indonesian context, the Islamic philanthropy potential is still prodigious to be managed and developed. Seeing from the wisdom contained, in fact Islamic philanthropy has two dimensions: first, the individual dimension (wanting an individual change), reflected in the purification of the human self from vices such as greedy and miserly; secondly, the social dimension that is changing the social order to build a culture of social responsibility and mutual prosperity. ${ }^{5}$

5 Qurratul Uyun, "Zakat, Infaq, Shadaqah, Dan Wakaf Sebagai Konfigurasi Filantropi Islam,” Islamuna: Jurnal Studi Islam 2, no. 2 (2015): 218, doi:10.19105/ islamuna.v2i2.663. 
According to the National Amil Zakat Agency (BAZNAS), the potential for Muslim charity reaches 217 trillion rupiahs, equivalent to $10 \%$ of the value of the Indonesian State Budget in 2016. As a considerable potential, it can contribute significantly to the ummah self-reliance economy. However, as reported in Tempo.com, the potential has only been explored around $1.2 \%$ or equivalent to 3 trillion rupiahs. ${ }^{6}$

Furthermore, state authorities institutions and nongovernmental institutions manage the form of Islamic philanthropy (zakat, infaq, and sadaqah). The state institution formed and regulated the function of Islamic philanthropy is the Badan Amil Zakat (zakat charity agency BAZ). Institutionally have a standard structure management hierarchy under the state administration. The highest structure is in the headquarter usually located in capital city and the lowest at the sub-district level. The president authorizes BAZ headquarters. The Governor authorizes in the provinces and so on up to the sub-district level. Baznas as the zakat management authority in Indonesia nationally records merely two percent of the potential that has been explored from the ummah. ${ }^{7}$ Thus, BAZ in national wide work regulate by the government enactment No. 23/2011 known as BAZNAS (Badan Amil Zakat National).

In addition to being managed by BAZNAS, zakat funds are also collected and managed by non-governmental organizations engaged in Islamic philanthropy. The institution that carries out the activity of raising and managing zakat funds is called the Lembaga Amil Zakat (amil zakat Institution LAZ). This institution task is dealing with collecting and distributing zakat. LAZ performs in all levels, from local, regional to national. The Ministry of Religion of the Republic of Indonesia supervises the management and performance of

\footnotetext{
${ }^{6}$ Vindry Florentin, "Baznas: Potensi Zakat Di Indonesia Mencapai Rp 217 Triliun | Kabar_puasa.Tempo.co,” Tempo.Co, 2016, https://m.tempo.co/read/news/2016/06/ 07/151777667/baznas-potensi-zakat-di-indonesia-mencapai-rp-217-triliun.

7 Ihsanuddin, "Baznas: Pembayaran Zakat Di Indonesia Hanya 1,3 Persen Dari Potensi," 2016,https://nasional.kompas.com/read/2016/06/30/11043871/baznas.pem bayaran.zakat.di.i ndonesia.hanya.1.3.persen.dari.potensi.Penulis.
} 
LAZ. Amil zakat institutions collect the zakat funds under the consideration of Indonesian enactment No. 38 of 1999. It states that zakat manageable by community initiatives organizations called LAZ and government organization called BAZ. A research result shows that religiosity, psychological, social factors and government regulation have positive and significant impact on society motivation in paying zakat through amil zakat agency. Partially, religious factor and psychological factor influences society motivation in paying zakat while social factor and government regulation does not influence it. ${ }^{8}$

In 2017, BAZNAS recommended 17 amil zakat institutions at the national level, the regional scale of the province, and at the district or municipality scale. Those institutions play a crucial role in the distribution and dissemination of Islamic philanthropic messages (zakat infaq sadaqah). In 2018 amil zakat institutions registered at the Ministry of Religion increased joined with Dompet Dhuafa Republika, BAZNAS (National Amil Zakat Agency), Inisiatif Zakat Indonesia, Yatim Mandiri Surabaya, NU CARE LAZIS NU (Lembaga Amil Zakat Infak dan Shadaqah Nahdhatul Ulama), LAZIS MU (Lembaga Amil Zakat Muhammadiyah). The following is a list of recognized Amil Zakat Institutions and several institutions initiating ZIS socialization, collection and distribution activities.

Table.1 Amil Zakat Institution

\begin{tabular}{cll}
\hline \multirow{2}{*}{ No } & \multicolumn{2}{c}{ Regional } \\
\cline { 2 - 3 } 1 & Rumah Zakat Indonesia & \multicolumn{1}{c}{ Province } \\
\hline 2 & $\begin{array}{l}\text { Lembaga Manajemen Infak } \\
\text { Ukhuwah Islamiyah }\end{array}$ & Semai Sinergi Umat \\
\hline 3 & Dana Sosial Al Falah Surabaya & $\begin{array}{l}\text { Dompet Amal Sejahtera } \\
\text { Ibnu Abbas (DASI) NTB }\end{array}$ \\
\hline 4 & Pesantren Islam Al Azhar & Dompet Sosial Madani \\
\hline
\end{tabular}

8 Ahmad Ajib Ridlwan and Raditya Sukmana, "The Determinant Factors of Motivation to Pay Zakat in Regional Amil Zakat Agency of East Java," KARSA: Journal of Social and Islamic Culture 25, no. 2 (2018): 334, doi:10.19105/ karsa.v25i2.1398. 


\begin{tabular}{cll}
\hline & & (DSM) Bali \\
\hline 5 & Baitulmaal Muamalat & Harapan Dhuafa Banten \\
\hline 6 & Global Zakat & Solo Peduli Ummat \\
\hline 7 & $\begin{array}{l}\text { Dewan Da'wah Islamiyah } \\
\text { Indonesia }\end{array}$ & $\begin{array}{l}\text { Dana Peduli Umat } \\
\text { Kalimantan Timur }\end{array}$ \\
\hline 8 & Perkumpulan Persatuan Islam & \\
\hline 9 & $\begin{array}{l}\text { Rumah Yatim Arrohman } \\
\text { Indonesia }\end{array}$ & \\
\hline
\end{tabular}

Source: Researcher (2018)

Islamic philanthropic institutions uses the substance principle of inviting and preventing in distributing conveyed message. It should be in Islamic pearls of wisdom that in conveying messages, it should be in an ethical manner (ma'ruf). Message content delivered in addition to containing the values of the invitation to positive things. Meanwhile, in some segments, there are messages that encourage people to leave the negative one. The pattern of communication refers to the way $(a d a b)$ of communication carried out by the prophet Muhammad. Prophet Muhammas is the best role model in his behavior among doing business or everyday life. ${ }^{9}$

The growth of prophetic communication scholarship is a reaction to the neocolonial discourse, which considers with media industry practices that lead to dehumanization. ${ }^{10}$ This concept refers to the communication patterns exemplified by the Prophet Muhammad with religious, moral, and ethical values embedded. ${ }^{11}$ As the most

${ }^{9}$ Saiful Hadi, "Building Economic Intelligence in the Perspective of Islamic Values through a Family Education in Madura," KARSA: Jurnal Sosial Dan Budaya Keislaman 24, no. 2 (2016): 205, doi:10.19105/karsa.v24i2.891.

10 Fitri Yanti, "Meneropong Paradigma Komunikasi Profetik," Jurnal Ilmu Komunitas Dan Pengembangan 9, no. 1 (2014): 45-56, http://ejournal.radenintan. ac.id/index.php/alummah/article/view/578.

11 Ade Abdul Hak et al., "Using Electronic Media and Problems of Prophetic Communication Behavior at UIN Syarif Hidayatullah Jakarta" 154, no. Icclas 2017 (2018): 55-58, doi:10.2991/icclas-17.2018.14. 
significant number of Muslims countries, these patterns could derive as the genealogy of Indonesian communication daily. Interdisciplinary prior communication studies from other disciplines integrate to study the prophetic communication.

Communication scholar -Marshall McLuhan-state the medium is the message. Channel plays not only in a mechanical way but also implies with the cognitive domain, message design selection, and the determination of logical coherence. It requires conceptual recognition and message distribution skill. Prophetic communication prioritizing transcendental motivational preferences as a guide in the message production mechanism. Prophetic communication can be present in every message delivery, including the spread of Islamic philanthropic messages. It is more interested to study the uniqueness and idiosyncratic values of prophetic communication behind the philanthropy message. This research aims to explore the representation of prophetic communication values in messages distributed by Islamic philanthropic institutions.

The role of Islamic philanthropic institutions in the distribution of altruism and prophetic messages increasingly shows a tendency to develop and become more professional. The transcendental values involve in smooth and contemporary message format packaging. The message production principles usage in message design, selection, and distribution by Islamic philanthropic institutions shows positive performance and acquires appreciation. The fast growing of various Islamic philanthropic institutions with specifications of generosity shows the increasing tendency to explore the Indonesia Muslims potential donations. Furthermore, those benefits encourage Indonesia development. These philanthropic institutions initiate forms in various Islamic philanthropy activities.

\section{Methods}

This study uses qualitative document analysis method (Qualitative Document Analysis). QDA is oriented towards a series of investigative steps from the perspective of researchers to obtain concepts, data, and other sources of information contained in the 
context of thought processes and findings in research. ${ }^{12}$ Altheide ${ }^{13}$ calls this method the ethnographic content analysis method (ECA). QDA or ECA is used to elaborate prophetic communication protocols contained in texts distributed by Islamic philanthropic institutions. This method emphasizes concept development, data collection, and data analysis by using repeated studies to bring up findings on the message content. The corpuses in this study were nine (9) text messages from three ZIS institutions namely: YDSF (Dana Al Falah Foundation), RZ (Rumah Zakat), and LMI (Infaq Management Institute) distributed through the agency's website platform.

Protocol or unit of analysis refers to the thematic substance that can be raised as part of the repetition of the meaning of the material (corpus). This technique can be used for developing theories or as researchers' initial understanding of the phenomenon under study (Gormly 2004). In this study is guided by a background in the study of prophetic communication concepts. The unit of analysis in this study split into three categories: (1) transcendental orientation in the distribution of Islamic philanthropic messages, (2) humanization in the meaning of messages and (3) liberation of Islamic philanthropic texts. The findings in the analysis will be discussed with message production theories: goal-plans-action theory, action-assembly theory, and cognitive dissonance theory.

\section{Results}

The analysis worked on nine texts from three Islamic philanthropic institutions: Rumah Zakat (RZ), Yayasan Dana Sosial Al-Falah (YDSF), and Lembaga Manajemen Infaq (LMI). Unit analysis use protocol units from the prophetic communication

\footnotetext{
12 Patricia Leavy and Sharlene Nagy Hesse-Biber, "Historical Context of Emergent Methods and Innovation in the Practice of Research Methods," in Handbook Of Emergent Methods, ed. Sharlene Nagy Heser-Biber and Patricia Leavy (New York: The Guildford Press, 2008), 17.

13 David L. Altheide, "Reflections: Ethnographic Content Analysis," Qualitative Sociology 10, no. 1 (1987): 65-77, doi:10.1007/BF00988269.
} 
principles: humanization, liberation, and transcendental motivation. Theoretical framework underlying this research conducted as unit analysis. The philanthropic message conveyed by Islamic philanthropic institutions emphasizes the principle of communication by taking the example of the Prophet Muhammad. Encoding of messages carried out in Islamic philanthropic texts cannot be separated from the concept of the root of communication in the Qur'an. Nurdin $(2014)^{14}$ writes that the principle of communication in the Qur'an is the merging of immaterial (heart) elements with material elements such as hearing and seeing. The meeting of the two entities can give rise to thinking stages. The roots of communication in the Qur'an include all dimensions in communication from intrapersonal to mass communication.

\section{a. Humanization in philanthropic messages}

Islam already teach Muslim about generosity value since a centuries. Qur'an and the Prophet Muhammad exemplified regulate all Muslim life activities. More specifically prophetic communication refers to the prophetic communication patterns that have been carried out by the Prophet Muhammad and present as Muslims reference in repacking the preaching message in a contemporary context. In contemporary scientific studies the term prophetic communication become a renowned.

The first principle marked in prophetic communication messages is humanization. Humans are equipped with a desire to receive humanizing messages. As a recipient of the message, humans can recode encryption (decoding) of the message it receives. Diverse references from the recipient of the message, making the selection strategy or design of the message should be a commodity principle of strategy in marketing communication by focusing on 3P. First, affect the last consumer (end-user) with pull-positioning strategies. Second, push-positioning strategies, which aim to influence the buyer's marketing channels. Third, profile-positioning strategies to influence

\footnotetext{
${ }^{14}$ Ali Nurdin, “Akar Komunikasi Dalam Al-Qur'an,” Jurnal Kajian Komunikasi 2, no. 1 (2014): 12-26, doi:10.24198/jkk.vol2n1.2.
} 
more stakeholders' not just consumers or parties involved in the distribution chain. ${ }^{15}$

Humanization in the context of prophetic communication refers to the awareness that humans must be humanized in essence. This summons in the rules of prophetic communication is a form of humanization of the human right which every individual has the right to happiness. According to the Indeks Kebahagiaan Nasional (Gross National Happiness Index) is intended to direct people and nations towards happiness, especially by improving the conditions of people who are not contented. For policy actions, the IKN index allows the government and other parties to increase the percentage of people who are happy or reduce the conditions of those who are uncontented. ${ }^{16}$

In this case, the message of Islamic philanthropy is brought closer to the character of the Prophet Muhammad. The principle of humanization in prophetic communication (amar ma'ruf) is refers to summons, signs use and code systems that lead to persuasive communication. The messages conveyed are more to do positive things call both for personal goodness and for social piousness. Texts from three philanthropic institutions from the corpus analyzed that show the summons text are contained in the message as below

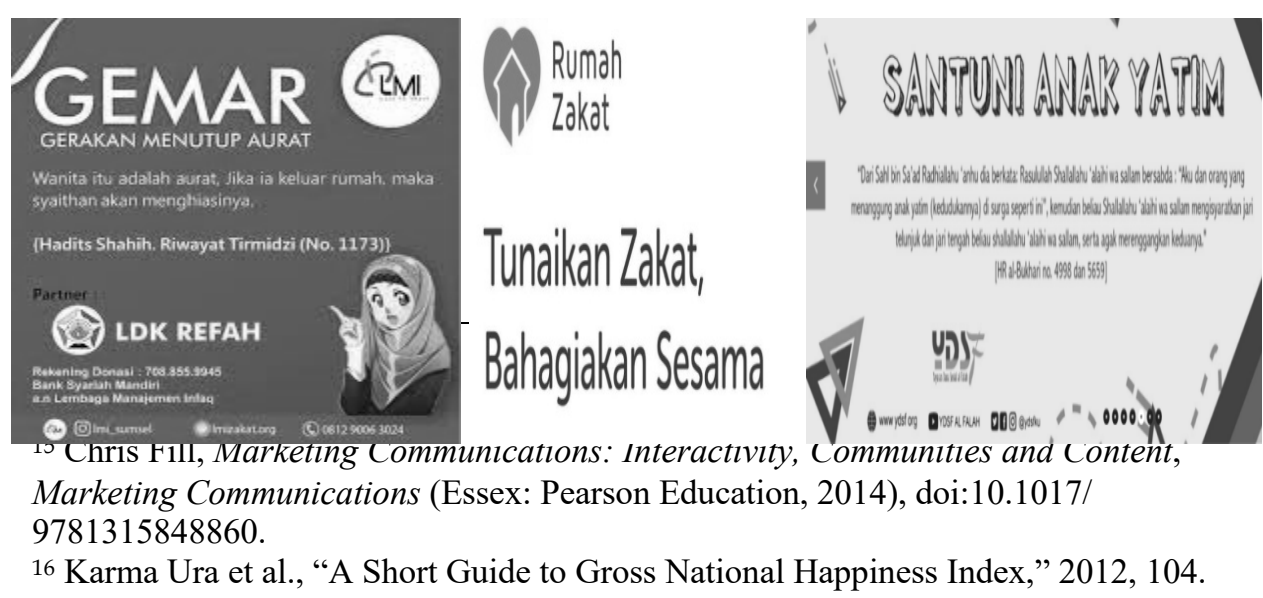

Copyright (c) 2020 by Karsa. All Right Reserved

DOI: 10.19105/karsa.v28i1.2807 
Source: rz.org, ydsf.org, lmi.org.

Fig 1. Humanitation Texts

The series of diction selected in the three texts carries the spirit content to do what is instructed in Islamic teachings. In the LMI text "Gerana Menutup Aurat" (aurat covering movement) included the argument referred to hadith Sahih History Tirmidhi No.1173. The first manuscript uses a sign with the sentence that women are aurat ${ }^{17}$, and then this message invites women to willingly close some of the limbs placed as a private parts. This summons in marketing rules will not bring any profit to the message planner or communicator. However, in the rules of advertising, the message will give an impact to the sender is not always in the form of material. ${ }^{18}$ By persuading goodness, the message given by the communicator (philanthropic institution) becomes a long-term investment in understanding the rules of religious virtues. The pattern of packaging design in the rules of message production uses the principle that all objectives require instruments.

In the second draft of YDSF, summons people to support orphans in accordance with the argument of HR. 4998 and 5659 carry out persuasion. The narrative in the text refers to that people who care for and love orphans will have a close position with the Prophet Muhammad. Encoding carried out in the text in the perspective of goal-plans-action theory implies philanthropic motivation. The choice of words in a message is a form of action from a series of other purposeful actions. The success of a message design after being

\footnotetext{
${ }^{17}$ Parts of the body that are not allowed to be shown to the public except to certain people

18 John Cooper et al., "Marketing Communication: Sending the Message," in Practical Marketing Planning, 1997, 133-44, doi:10.1007/978-1-349-25551-1_11.
} 
evaluated by the sender will be used as one of the references in making the next message design.

Whereas the Rumah Zakat institution reminds humanization in its text which implies that giving alms, there will be happy fellow brothers. The choice of the word "tunaikan zakat, bahagiakan sesama" (pay alms, make each other happy) contextually does not stop at the form of charity or momentary donations. Its significance as one of the central pillars of Muslim faith, and the principles through which it addresses the relief of poverty and the redistribution of wealth. Islamic conceptions of state and community are then explored and the ways in which Muslim faith and culture are adapting at both the global and community leve..$^{19}$ Charitable giving is one of the major obligations Islam and a strong Muslim norm endorses giving to the needy, but discourages public displays of giving. This norm is puzzling in light of previous evidence, suggesting that making donationspublic often increases giving. ${ }^{20}$

The message wants the form of assistance given to fellow Muslim brothers and sisters to bridge sustainable happiness. ${ }^{21}$ The happiness that Muslim brothers get with donations from the people is the happiness of donors. By giving a sincere donation, in essence, the donor is undergoing a business to have a blessed age that is a useful age for others. Islam teaches that the age of blessing is an indicator of human happiness.

The message preceding can be understood as the warmth in the "commandment" not to be forceful but rather to provide positive agitation for the understanding of the people who are still unfamiliar about the obligation in religion. The texts attach ethical and normative references as reinforcement of the message delivered. In terms of prophetic communication, persuasive messages to do good (amar

\footnotetext{
19 Hartley Dean and Zafar Khan, "Muslim Perspectives on Welfare," Journal of Social Policy 26, no. 2 (1997): 193-209, doi:10.1017/S0047279497004972.

${ }^{20}$ Fatima Lambarraa and Gerhard Riener, "On the Norms of Charitable Giving in Islam: A Field Experiment” (Düsseldorf, 2012), https://www.econstor.eu/bitstream/10419/59571/1/718795458.pdf.

${ }^{21}$ Ibid
} 
ma'ruf) get a place parallel to messages that indicate prevention of crime (nahi munkar). The community transformed both in dialectical externalization, objectivation, and internalization. Prophetic communication implies in philanthropic institutions texts of a contemporary dimension is one of the efforts to make this transformation occupy compliance gaining, empowerment, and strength of Islamic philanthropy. Objectives discovery remind welfare of the people in halal and thoyib is rahmatan lil 'alamin manifestation.

Human beings are united entities which not partial but scripturalist and substantialist, they are free from alienation. Humans are active creatures who rationally search for truth by approaching religious texts such as the holy book. This view is contrary to the opinion of Karl Marx approaching alienation as a form of human alienation from the human side caused by a shift in the portrait of society into an industrialist society with indicators of materialistic achievement. Hedonism is one form of dehumanization in the rules of humanity.

Prophetic in the rules of humanitarian practice is brought closer to the ethical category in looking at social phenomena. The presence of prophetic communication to restore messages as contact is not only between texts (verses) but also 'ilm (science) and philosophy. The message shared in the three texts above shows the commitment of philanthropic institutions to package philanthropic messages in a prophetic framework with a persuasive approach. Normative ethical rules embed with the rules of humanity message.

\section{b. Liberation in Islamic philanthropic messages}

The second principle of prophetic communication is messages liberation. Another rule proclaims it as nahi munkar principle whereas to prevent untruth message. The Prophet taught action when Muslims saw something wrong in front of them. Rasulullah's shows a series of punctuated events from mundane to elaborated mechanism to eliminate misdeed. The first rule, if people have power, they should prevent crime with that power. Second, if they do not have any, they can 
remind verbally. Furthermore, the third rule is praying as the perpetrators get guidance.

Prophetic communication provides corrections to the rules of pouring "free" messages as brought by libertarianism. ${ }^{22}$ There is an incorrect understanding of the presence of libertarianism in viewing the presence of state freedom and authority. Some libertarianism sees an extreme form of absolute freedom in individuals, and others consider libertarian to be a permissive form of exploitation of the working class by capitalists. Libertarianism fights for the recognition and protection of individual rights as a fundamental element embeds with tolerance, volunteerism, and peace values. ${ }^{23}$

The message liberation concept in prophetic communication refers to the freedom of humans nature to choose and preference of message. In this context, the message shared in the concept of prophetic communication must fulfill the truth and sincerity even if it is in the context of reminding others.

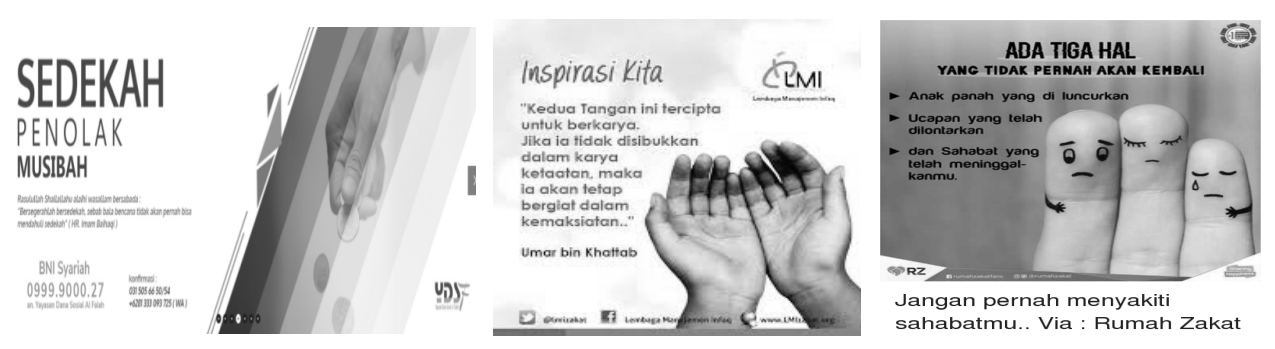

Source: rz.org, ydsf.org, lmi.org.

Fig 2. Message liberation

The text above shows the rules of the liberation of a message.

Text producers (communicators) write more preventative texts: "sedekah menolak bencana" (voluntary giving reject disaster), "kedua

\footnotetext{
22 Monzer Kahf, "The Role of Waqf in Improving the Ummah Welfare," The International Seminar on Waqf as a Private Legal Body, 2003, 1-26, http://monzer.kahf.com/papers/english/ROLE_OF_WAQF_IN_THE_WELFARE_O F_THE_UMMAH.pdf.

${ }^{23}$ Jason Brennan, Libertarianism: What Everyone Needs To KNow (New York: Oxford Unversity Press, 2012.
} 
tangan ini tercipta untuk berkarya dalam ketaatan dan bukan kemaksiatan" (these two hands were created to work in obedience and not infringement), and the aphorism to "tidak boleh menyakiti sahabat" (do not hurt friend). In the context of Islamic philanthropy, the moral obligation of the wealthy people to help their needy siblings or kin is not only interpreted as mere financial donation activities but also reminding their brothers not to do damage. Message distributed by Islamic philanthropic institutions above carries preventive texts messages about prohibited things in religious verses. The manuscript layout design includes the institution identity. However, it is emphasizing more on the liberation message of fundraising interests. The message of liberation conveys exposure to communicant audiences.

The liberation manifested in Islamic philanthropic institution texts with an ethical approach. Meanwhile, the rules of prophetic communication liberate into more universal texts with the common sense of some readers (qaulan maysura) consumption. Moreover, prophetic communication places humans in equilibrium. This condition refers to human spiritual stability becomes a consideration in prophetic communication. The management of prophetic communication messages requires a sufficient contribution to all such entities.

Message producer or recipient is not merely the single determinants in that process. The principle of liberation recognizes that humans have their own private identities. Despite de facto and de jure condition, certain social and other identities bound it. The variety of preferences, backgrounds, and tendencies will affect the mechanism of individual message reception. Placing the rules of publicity in making messages is a smart strategy for introducing marks to the general people. In the text above the message units such as words, illustrations, nirmawa dwimatra displayed attract people "warmly" to avoid things that are harmful without being accompanied by coercive or menaces texts.

Al Qur'an guides ummah on how to convey communication messages appropriately. Message design concept approaches persuasive communication effective with indicators of objectives 
communication achieving. The semantic approach to the use of qur'ani speech acts phrases becomes one of the rules in achieving the communication objectives. Sauri mentions that the lexical rules of using the principle of mildness (qaulan layyina) in bearing messages for people to leave darkness will be reminded of their obligations as Muslims and commit to abandoning religious restrictions. ${ }^{24}$

\section{c. Trancedental orientation among Islamic philanthropic messages}

The third protocol in prophetic communication is transcendental orientation. In other rules, consider it tu'minubillah, which rests all motivation on actions (words and deeds) merely to God. This precedent refers to a strengthened disposition of prophetic Muhammad imprints during the spiritual journey of Isra' Mi'raj. From this event, the term prophetic became more widely known. Prophetic reminds that all human ideas, activities, artifacts, and these entities combination should entangle impartial virtue dimension. All estuary and downstream intends to and only to God. Human social life is a necessity that is juxtaposed with personal life.

Transcendental orientation in Islamic philanthropic texts relates to "golden rules" in the religion understanding phenomenon. This transcendental principle brings reward elements orientation and form of the activity itself. Although in some understandings, the orientation of transcendence becomes an inseparable part of religious attitudes and behavior. Islamic philanthropic activists persuasive communication is an effort part for the religious altruism strengthen functions. The Islamic philanthropy advertisement went on decryption and illustration about all the diverse practices needed in transcendence orientation. Being kind and virtuous is not only an indicator of quantification of rituals but also appeals to broader social piety. Voluntary giving ${ }^{25}$ of

\footnotetext{
${ }^{24}$ Sofyan Sauri, Ibid

25 Thierry Kochuyt, "God, Gifts and Poor People: On Charity in Islam," Social Compass 56, no. 1 (2009): 98-116, doi:10.1177/0037768608100345. Islam asks the faithful to help the poor, and outlining the ideal type of this religious charity known as the zakat. See also Armiadi Musa, “Zakat in 'Qanun' (Aceh Local Law): The
} 
transcendental motivation becomes a crucial point in managing the Islamic philanthropy message.
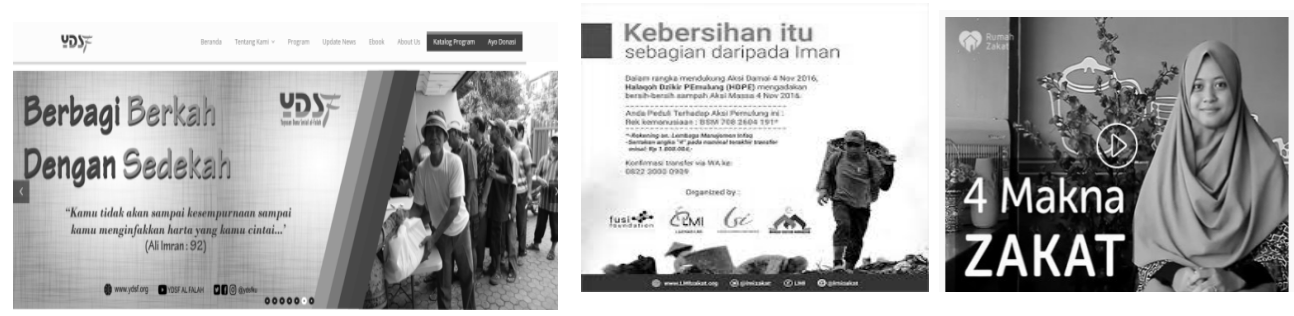

Source: rz.org, ydsf.org, lmi.org.

Fig 4. Transcedental dimension

Social reality is dynamics and dialectics fluidly. Prophetic communication presents a substance of the afterlife warning. Humans move with styles variety and personifications but always remembering the being fundamental nature. The messages captured from figure 4: "berbagi dengan sedekah" (sharing with alms), "kebersihan itu sebagian daripada iman" (cleanliness is part of faith), "I" (the meaning of zakat) shows the presence of the God dimension in the description of Islamic charity activities. The message in Islamic rules beyond transmitted information, it is also must meet the forthright rules (qaulan baligha). The manuscript is delivered eloquently to impress the communicant's soul and create effective communication

Impact to Zakat Management as the Local Government Original Revenues in Baitul Mal of Aceh [ الزكاة في ‘القانون' (النظام المحلي في آتشيه): تأثير إدارة الزكاة كالإيرادات الأصلية [للحكومة المحلية في بيت المال الآتشي : KARSA: Journal of Social and Islamic Culture 26, no. 1 (2018): 150, doi:10.19105/karsa.v26i1.1832. It is also revealed that zakat is considered as one of the sources of the original revenues of the local government (PAD) and is managed by Baitul Mal, whether at the level of Aceh province or at the level of the municipality and the city. 
indeed. ${ }^{26}$ This rule apply in the terminology of the communicator's ability to convey a message with a context of the nature of the communicant audience as a discussion strategy. ${ }^{27}$

Rituals in spiritual experience context is more recognizable than religiosity. The spiritual experience felt by each philanthropist will differ from one entity to another. The relative inclination makes prophetic communication a reminder that in all searches of spiritual experiences both its implicit and explicit nature, it must present divine power. In this context, there is not a single text of human life without a transcendental dimension. Of all the texts managed by philanthropic institutions (RZ, YSDF, and LMI) it has a transcendental dimension. One of the philanthropic institutions' interests toward transcendental dimension is one of them carried out by reminding people with transcendental protocols referenced from the prophet Muhammad activities.

Writing references from each submitted Islamic philanthropic institutions manuscript shows the text principle of truth. Ethically, the mechanism of carrying references from the Qur'an, hadiths, or sahabat opinions is a precautionary principle to convey the message correctly and deception avoidance (qaulan sadida). ${ }^{28}$ To convey a good message requires a proper manner and selective methods. The suitable rule in this context is to convey the message by putting forward quality maxims as sincere truth message giving. Signs delivered should represent the constructive meaning.

\footnotetext{
${ }^{26}$ Ahmad Atabik, "Konsep Komunikasi Dakwah Persuasif Dalam Perspektif AlQur'an," AT-TABSYIR: Jurnal Komunikasi Penyiaran Islam 2, no. 2 (2015): 117-36. 27 Eva Maghfiroh, "Komunikasi Dakwah; Dakwah Interaktif Melalui Media Komunikasi," Dakwatuna: Jurnal Dakwah Dan Komunikasi Islam 2, no. 1 (2016): $34-48$.

${ }^{28}$ Sofyan Sauri, "Pendekatan Semantik Frase Qaulan Maysura, Layyina, Dan Karima Untuk Menemukan Konsep Tindak Tutur Qurani," n.d., http://file.upi.edu/Direktori/FPBS/JUR._PEND._BAHASA_ARAB/1956042019830 11SOFYAN_SAURI/jurnal2/PENDEKATTAN_SEMANTIK_ _ FRASE_QAULAN_ SADIDA.pdf.
} 
The use of straightforward principles went without reducing the context of respect for the target message (qaulan karima). The signs gave consistent coverage of transcendence value with the emphasize on politeness and gentleness. ${ }^{29}$ Kind word in diction choice mediates communicator and communicant in transcendental phrases. This follows the view that egalitarian entity is that which enhances equality obligation between communicator and communicant as a partner in dialogue.

\section{Discussion}

Islamic philanthropic institutions employ politics of message to maximize the people altruism potential. In this case, it means that the communication strategy used by Islamic philanthropic institutions refers to persuasive communication patterns. The principle of "touching" invites people to be more involved in the activities of Islamic charity. Those institutions use the Prophet Muhammad pattern of communication reference in conducting charity messages production. The principle of prophetic communication is to emphasize the three main pillars of humanization, liberation, and transcendental orientation in a message.

${ }^{29}$ St Mislikhah, “Ar-Raniry: International Journal of Islamic Studies Vol. 1, No.2, Desember 2014 (www.journalarraniry.com) | St” 1, no. 2 (2014): 285-96. 


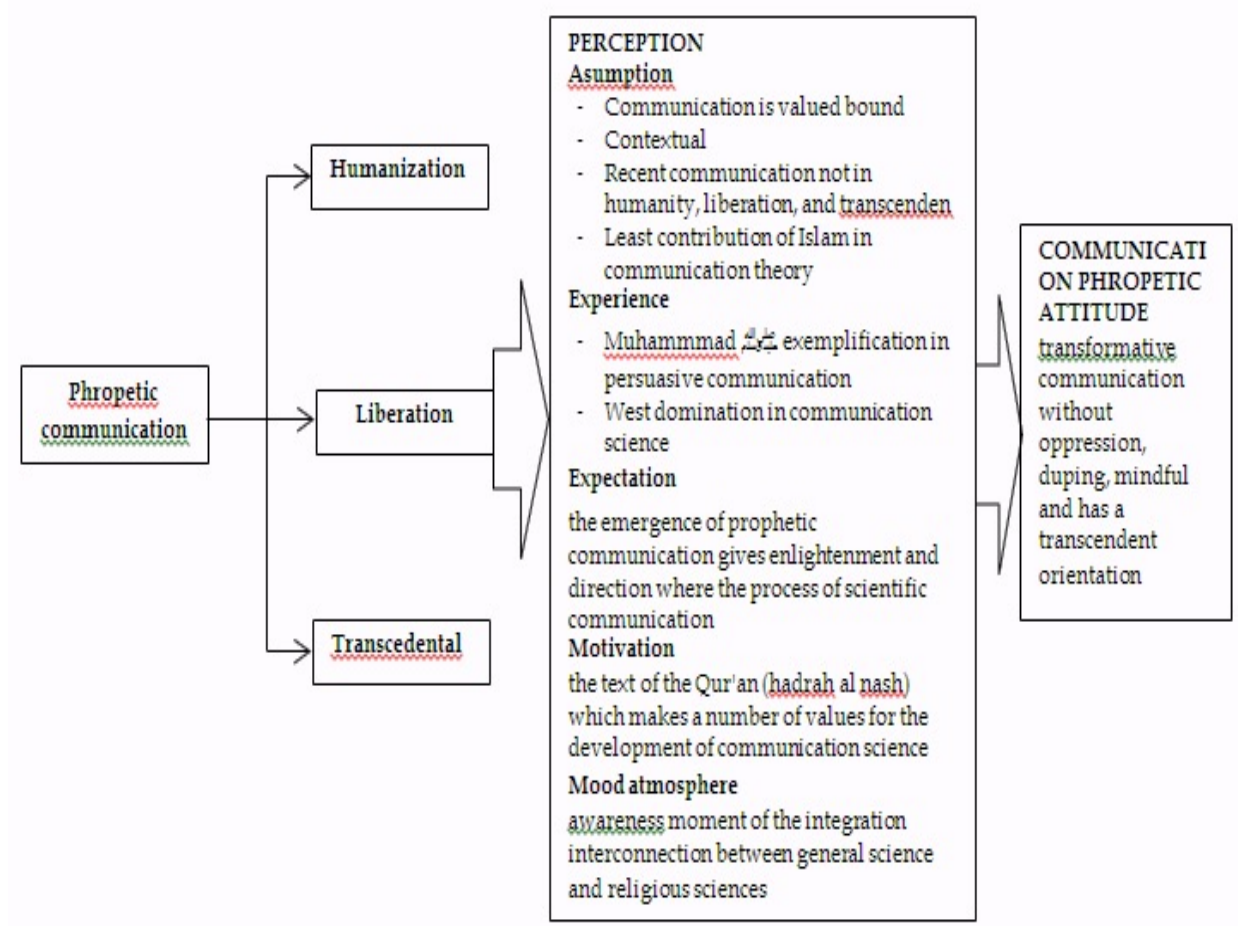

Fig 3. Prophetic communication principals

This political message design applies to made closer to its audience. This pattern brings the text of Islamic philanthropy in the context of behavior which is not only normatively accepted by his followers while at the same time drawing closer to social propriety or in other terms calling it politeness. Burgon's terminology in Littlejohn ${ }^{30}$ calls the involvement of communicator interaction positions with demands, expectations, and desires in communication as RED (requirements, expectations, desires. The purpose of delivering

30 Stephen W Littlejohn and Karen A Foss, Encyclopedia of Communication Theory (California: Sage Publications, Inc, 2009). 
messages is part of the planning itself. This principle is referred to as meta goals, which will direct the plans made in the production of messages. The daily behavior of the people delivers in Islamic institutions narrative texts.

In a communication perspective, the distributed messagesincluding Islamic philanthropic messages - have a specific purpose. Communication message effectiveness employs three models: linear, interactional, and transactional. The communicators use management processes in message making designs. The purpose of creating communication messages becomes essential concerning the meaning of the message presented. Messages in communication are encoded or encoded (decoding) using a set of rules (maxims). Ferdinand De Saussure stated that the involvement of a series of linguistic logic and codes with everyday practice becomes a combination of langue and parole. Message derived as significant element in the communication process. Sensory decode information as stimulus and become a part of message responses. Signal between providers transmit message in texts form. However, in other contexts, the text is a construction of meaning.

Humans are storytelling animals who generally like character narratives delivered. Another rule states as a mechanism for distributing messages with the values of ma'ruf. Since the prophetic period, a decent way (ma'ruf) employ in a message through communication. This concept is conformable with the thesis of message production theory. Littlejohn ${ }^{31}$ shapes cognitive rules, which emphasize several protocols (maxims) for effective communication in the message production theory: the principle of habits (traits), behaviors, and cognitive approaches. In the rules of message production, communicator work with three major components: planning and action message selection, and message design.

The message designs making as practiced by Islamic philanthropic institutions converges on persuasion form. There are two

31 Stephen Littlejohn, Karen Foss, and Julie Yingling, "Communication and Language Acquisition and Development," in Encyclopedia of Communication Theory, 2012. 
principles of cognitive tradition in the design of persuasion messages: strategy selection and goal pursuit. ${ }^{32}$ Meanwhile, in achieving goals in message design there are at least sixteen mechanism. ${ }^{33}$ Communicants' compliance gaining use the message design submission. Manuscripts that contain the values of humanization found such as mention of invitations sentences such as: "Gerakan Menutup Aurat" (wearing veil movement), "Santuni Anak Yatim" (charity to orphans); "Bayar Zakat" (paying alms) is a form of positive altercating strategy which emphasizes the communicant as a great people who have immeasurable qualities.

Cognition dissonance theory can be used to explain the message strategies created by philanthropic institutions. Cognitive dissonance theory (CDT) has four assumptions. ${ }^{34}$ First, humans want consistency in beliefs, attitudes, and behaviors. Second, psychological inconsistencies create dissonance. Third, it is an unpleasant condition that drives people to act with effects measurable. Fourth, dissonance motivates achievement efforts for consonants and toward misconception reduction. Islamic philanthropic institutions messages display uses adjusted context narration. In the context of Islamic philanthropic institutions, the CDT approach is conducting the values of certain beliefs and with prophetic communication behavior to initiating attitude change among the public.

The goal-plans-action theory explains that the motives for making messages in communication cannot always be singular. ${ }^{35}$

\footnotetext{
32 Wilson, Steven R. "Developing Theories of Persuasive Message Production: The Next Generation"." Dalam Message Production : Advances in Communication Theor, oleh John O Greene (ed). Mahwah, New Jersey: Erlbaum, 1997.

${ }^{33}$ Gerald Marwell and David R Schmitt, "Of Compliance-Gaining Dimensions Behavior: An Empirical Analysis *" 30, no. 4 (2014): 350-64.

${ }^{34}$ Richard West and Lynn H Turner, Introducing Communication Theory: Analysis and Application, Journal of Chemical Information and Modeling, 4th ed., vol. 53 (New York: McGraw Hill, 2010).

${ }^{35}$ Carma L. Bylund, Emily B. Peterson, and Kenzie A. Cameron, “A Practitioner's Guide to Interpersonal Communication Theory: An Overview and Exploration of Selected Theories," Patient Education and Counseling 87, no. 3 (2012): 261-67, doi:10.1016/j.pec.2011.10.006.
} 
Humanization of the philanthropic text above not only brings marketing value to the programs offered by the institution but at the same time can bring other motives. The motives for setting goals in communication messages can range from individual ego reasons to manifestations of altruism, from the desire to show oneself to philanthropic reasons. ${ }^{36}$

The principle of delivering messages with the phrase ma'rufa refers to the applying society ethical generally values. This message design in a simple manner encourages the readers to chance Islamic philanthropic institutions as active stakeholders. This approach is an opportunity for Islamic philanthropic institutions to provide additional knowledge and insight from the texts in the message delivered. A good text considers as something good in the view of the community in the environment of the speaker (communicator). Although in another perspective, it is stated that the delivery of the qaulan ma'rufa rules is more appropriately compliance with the law and logical inferences. ${ }^{37}$

The action-assembly theory perspective states that in the rules of message design, there are two components of knowledge: content knowledge and procedural knowledge. The rule of making a message depends not only on the communicator's ability to know what message is to be delivered but also on the protocol of how to convey it. The procedure in making message design in communication through five points ${ }^{38}$. First, a focus on message encoding processes, where output becomes part of the strategy compared to input processes. Second, a commitment to a human information-processing approach to message encoding, from this perspective the phenomenon of human behavior is born from the operation of the structure of information that has a specific charge. Third, a hybrid intentional/functional stance, although

\footnotetext{
36 James Price Dillard and David C. Schrader, "Reply: On the Utility of the GoalsPlans-Action Sequence," Communication Studies 49, no. 4 (1998): 300-304, doi:10.1080/10510979809368540.

37 Sofyan Sauri, Ibid

38 John O. Greene, "Production of Messages in Pursuit of Multiple Social Goals: Action Assembly Theory Contributions to the Study of Cognitive Encoding Processes," Annals of the International Communication Association 18, no. 1 (1995): 26-53, doi:10.1080/23808985.1995.11678906.
} 
in the sense of cognition involves the goals and knowledge of the communicator but is limited by the fact of the prediction of the assumption of rationality will message received or rejected by the communicant. Fourth, an effort to locate multiple-goal message production within a more encompassing theoretical framework, this theory works with the issuer to more broadly see the phenomenon from a variety of coherent perspectives. Fifth, an alternative conception of messages. Behavior plays like a collection of various elements organized hierarchically represented by some different symbolic codes ranging from abstract actions to in the form of phenomena of knowledge.

The packaging of messages in the distribution of philanthropic messages includes the selection, design, and action strategic decision making by amil zakat institutions. In general, philanthropy retains five pillars: fundraising, distribution, evaluation, and sustainability. Promoting persuasive communication held to generate the pillars. Amil zakat institutions bring Islamic philanthropy activities with persuasive communication and employ technological developments. All amil zakat institutions in this research synchronize convergence platform between the appearance and substance of philanthropic messages. The public could supervise institutional philanthropic activities with access to provided social media institution platforms. The funders could admittance the fundraising or collection of zakat funds and distribution management through various forms of channels, ranging from offline offices, community print media, or participating in the institution activities.

Philanthropic institutions went into kindness texts (amar ma'ruf) with liberation principle. Message packaging involves generality of universal values text conventions. Islamic philanthropic institutions placed humans beings as a free entities with human rights to use their individual capacities and abilities to perform worship in a constructive and positive context. Cognitive dissonance theory explains the choice of message design in advertising to be a perception. It contains both motivation and emotions. Human 
understanding of a stimulus (memory) for signs can occur oppositely. ${ }^{39}$ In this context, the message of Islamic philanthropy in the principle of prophetic communication tries to minimize the effects of dissonance, which arise from public knowledge differences.

\section{Conclusion}

From the analysis and discussion, It draw several conclusions about humanization principles, liberation, and transcendentalism in these texts. The warm impression captured from the text is the application of prophetic communication with the principle of the message liberation. The holding of the principle of liberation by Islamic philanthropic institutions can strategically escort the presence of preferred and polite texts. Islamic philanthropic texts emphasize the principles of humanitarian practice approach. Humanization depart with the principle of ease (qaulan maysura), the principle of politeness (qaulan ma'rufa), and the principle of gentleness (qaulan layina). Transcendence orientation dimension follows messages treatment in a straightforward but respectful way. This makes the messages management as involving a series of capacities and skills in the transactional model.

The dynamically and contemplatively social dynamics need studies demanding to contribute positively. The 4.0 communication era requires the convergence of communication technology and human strengthening. Communication science has been offering the principles of prophetic communication to face. The findings of the presence of prophetic communication in Islamic philanthropic texts indicate a connection between the normative scope and the empirical dimension in the study of the nature of communication. In this context, communication science is value bound with the rules of contextually consensus paradigmatic. In the future, there would be a combination of the dynamics of social systems and the development of communication technology union with the values in prophetic communication. Further

\footnotetext{
39 Stephen W Littlejohn and Karen A Foss, Encyclopedia of Communication Theory (California: Sage Publications, Inc, 2009).
} 
research can conduct studies by taking corpus from similar institutions with the selection of different media platforms. Looked forward to future studies can reach a more extensive text using quantitative content analysis methods.

\section{Bibliography}

Abdul Hak, Ade, Tine Silvana Rachmawati, Agus Rusmana, and Asep Saeful Muhtadi. "Using Electronic Media and Problems of Prophetic Communication Behavior at UIN Syarif Hidayatullah Jakarta" 154, no. Icclas 2017 (2018): 55-58. doi:10.2991/icclas17.2018.14.

Ahmad Atabik. "Konsep Komunikasi Dakwah Persuasif Dalam Perspektif Al-Qur'an." AT-TABSYIR: Jurnal Komunikasi Penyiaran Islam 2, no. 2 (2015): 117-36.

Altheide, David L. "Reflections: Ethnographic Content Analysis." Qualitative Sociology 10, no. 1 (1987): 65-77. doi:10.1007/ BF00988269.

Brennan, Jason. Libertarianism: What Everyone Needs To KNow. New York: Oxford Unversity Press, 2012.

Bylund, Carma L., Emily B. Peterson, and Kenzie A. Cameron. "A

Practitioner's Guide to Interpersonal Communication Theory: An Overview and Exploration of Selected Theories." Patient Education and Counseling 87, no. 3 (2012): 261-67. doi:10.1016/ j.pec.2011.10.006.

Cooper, John, Peter Lane, John Cooper, and Peter Lane. "Marketing Communication: Sending the Message." In Practical Marketing Planning, 133-44, 1997. doi:10.1007/978-1-349-25551-1_11.

Dean, Hartley, and Zafar Khan. "Muslim Perspectives on Welfare." Journal of Social Policy 26, no. 2 (1997): 193-209. doi:10.1017/S0047279497004972.

Dillard, James Price, and David C. Schrader. "Reply: On the Utility of the Goals-Plans-Action Sequence." Communication Studies 49, no. 4 (1998): 300-304. doi:10.1080/10510979809368540.

Dogarawa, Ahmad Bello Dogarawa. "Poverty Alleviaton through 
Zakah and Waqf Institutions: A Case for the Muslim Ummah in Ghana.” SSRN Electronic Journal, 2012. doi:10.2139/ ssrn. 1622122 .

Fārūqī, Ismā‘îl Rājīi al. "THE PRINCIPLE OF THE UMMAH.” In $A l$ Tawhid, 103-28, 2019. doi:10.2307/j.ctvk8w28n.12.

Fill, Chris. Marketing Communications: Interactivity, Communities and Content. Marketing Communications. Essex: Pearson Education, 2014. doi:10.1017/9781315848860.

Florentin, Vindry. "Baznas: Potensi Zakat Di Indonesia Mencapai Rp 217 Triliun | Kabar_puasa | Tempo.co.” Tempo.Co, 2016. https://m.tempo.co/read/news/2016/06/07/151777667/baznaspotensi-zakat-di-indonesia-mencapai-rp-217-triliun.

Greene, John O. "Production of Messages in Pursuit of Multiple Social Goals: Action Assembly Theory Contributions to the Study of Cognitive Encoding Processes." Annals of the International Communication Association 18, no. 1 (1995): 26-53. doi:10. 1080/23808985.1995.11678906.

Grice, H. P. "Grice (1975)- Logic and Conversation." In Syntax and Semantics 3: Speech Arts, 41-58, 1975. http://www.com municationcache.com/uploads/1/0/8/8/10887248/logic_and_conv ersation.pdf.

Hadi, Saiful. "Building Economic Intelligence in the Perspective of Islamic Values through a Family Education in Madura." KARSA: Jurnal Sosial Dan Budaya Keislaman 24, no. 2 (2016): 205. doi:10.19105/karsa.v24i2.891.

Ihsanuddin. "Baznas: Pembayaran Zakat Di Indonesia Hanya 1,3 Persen Dari Potensi," 2016. https://nasional.kompas.com/read/ 2016/06/30/11043871/baznas.pembayaran.zakat.di.indonesia.han ya.1.3.persen.dari.potensi. Penulis.

Kochuyt, Thierry. "God, Gifts and Poor People: On Charity in Islam." Social Compass 56, no. 1 (2009): 98-116. doi:10.1177/0037768 608100345.

Lambarraa, Fatima, and Gerhard Riener. "On the Norms of Charitable Giving in Islam: A Field Experiment." Düsseldorf, 2012. https://www.econstor.eu/bitstream/10419/59571/1/718795458.pdf 
Leavy, Patricia, and Sharlene Nagy Hesse-Biber. "Historical Context of Emergent Methods and Innovation in the Practice of Research Methods." In HANDBOOK OF EMERGENT METHODS, edited by Sharlene Nagy Heser-Biber and Patricia Leavy, 17. New York: The Guildford Press, 2008.

Littlejohn, Stephen, Karen Foss, and Julie Yingling. "Communication and Language Acquisition and Development." In Encyclopedia of Communication Theory, 2012.

Littlejohn, Stephen W, and Karen A Foss. Encyclopedia of Communication Theory. California: Sage Publications, Inc, 2009.

Maghfiroh, Eva. "Komunikasi Dakwah; Dakwah Interaktif Melalui Media Komunikasi." Dakwatuna: Jurnal Dakwah Dan Komunikasi Islam 2, no. 1 (2016): 34-48.

Marwell, Gerald, and David R Schmitt. "Of Compliance-Gaining Dimensions Behavior: An Empirical Analysis *" 30, no. 4 (2014): 350-64.

Mislikhah, St. "Ar-Raniry: International Journal of Islamic Studies Vol. 1, No.2, Desember 2014 (www.journalarraniry.com) | St" 1, no. 2 (2014): 285-96.

Monzer Kahf. "The Role of Waqf in Improving the Ummah Welfare." The International Seminar on Waqf as a Private Legal Body, 2003, 1-26. http://monzer.kahf.com/papers/english/ROLE_OF_ WAQF_IN_THE_WELFARE_OF_THE_UMMAH.pdf.

Musa, Armiadi. 'Zakat in 'Qanun' (Aceh Local Law): The Impact to Zakat Management as the Local Government Original Revenues

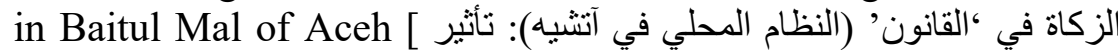
([إدارة الزكاة كالإير ادات الأصلية للحكومة المحلية في بيت المال الآتثي Journal of Social and Islamic Culture 26, no. 1 (2018): 150. doi:10.19105/karsa.v26i1.1832.

Nurdin, Ali. "AKAR KOMUNIKASI DALAM AL-QUR'AN.” Jurnal Kajian Komunikasi 2, no. 1 (2014): 12-26. doi:10.24198/ jkk.vol2n1.2.

Pew Research Center's Forum on Religion and Public Life. "The Future of the Global Muslim Population." Pew Research Center, 
2011. http://www.pewforum.org/2011/01/27/the-future-of-theglobal-muslim-population/.

Rakhmawati, Yuliana. "MADURA:" In MADURA: Masyarakat, Budaya, Media, Dan Politik, edited by Surokim, 117-34. Bangkalan: Elmatera Publishing, 2015.

Ridlwan, Ahmad Ajib, and Raditya Sukmana. "The Determinant Factors of Motivation to Pay Zakat in Regional Amil Zakat Agency of East Java." KARSA: Journal of Social and Islamic Culture 25, no. 2 (2018): 334. doi:10.19105/karsa.v25i2.1398.

Sauri, Sofyan. "Pendekatan Semantik Frase Qaulan Maysura, Layyina, Dan Karima Untuk Menemukan Konsep Tindak Tutur Qurani," n.d.

http://file.upi.edu/Direktori/FPBS/JUR._PEND._BAHASA_ARA B/195604201983011-

SOFYAN_SAURI/jurnal2/PENDEKATAN_SEMANTIK_FRA SE_QAULAN_SADIDA.pdf.

Ura, Karma, Sabina Alkire, Tshoki Zangmo, and Karma Wangdi. "A Short Guide to Gross National Happiness Index,” 2012, 104.

Uyun, Qurratul. "Zakat, Infaq, Shadaqah, Dan Wakaf Sebagai Konfigurasi Filantropi Islam." Islamuna: Jurnal Studi Islam 2, no. 2 (2015): 218. doi:10.19105/islamuna.v2i2.663.

West, Richard, and Lynn $\mathrm{H}$ Turner. Introducing Communication Theory: Analysis and Application. Journal of Chemical Information and Modeling. 4th ed. Vol. 53. New York: McGraw Hill, 2010.

Yanti, Fitri. "Meneropong Paradigma Komunikasi Profetik." Jurnal Ilmu Komunitas Dan Pengembangan 9, no. 1 (2014): 45-56. http://ejournal.radenintan.ac.id/index.php/alummah/article/view/5 78. 